\title{
A Brief Overview of Okinawan Separatism
}

\author{
Peter Simpson ${ }^{1}$ \\ ${ }^{1}$ Okinawa International University, Japan
}

\begin{abstract}
Okinawa and remaining islands of the Ryukyu Kingdom were militarily annexed into the emerging Japanese state in 1869, 260 years after their initial invasion and subjugation by forces from the Kagoshima Domain of the Edo Shogunate. In the centuries prior to this, the islands had emerged as an expanding trading kingdom, establishing tributary relations with Chinese, as well as Japanese centres of power. After the island's devastation in the last land battle of WWII, Okinawa was ruled for 27 years as a de facto US military colony, before its 1972 "reversion" to Japanese political control. Yet, almost $75 \%$ of US bases in Japan remain on the island, in the midst of its $1.4 \mathrm{~m}$ population, occupying almost a quarter of its territory. Ongoing political discontent, coupled with geographical, cultural and even spiritual distance would seem to provide fertile ground for a mass separatist movement. Nevertheless, since the reversion, mass protests have tended to coalesce around specific issues such as the representation of Okinawa in history textbooks, as well as ongoing disaffection and intermittent rage resulting from the US military presence. This paper suggests some historical, ideological and pragmatic explanations for the relative lack of a grassroots nationalist movement, and seeks to situate these in the context of Okinawa's collective memories and contemporary realities.
\end{abstract}

Keywords: separatism; residual and emergent nationalisms; Okinawa; Ryukyu; occupation

\section{Introduction}

On March 16, 2019, tens of thousands of protesters gathered in Naha, the Okinawan capital, as part of ongoing efforts to block the construction of a new United States military facility on the north-east coast of the prefecture's main island. The demonstration occurred in the context of a 23 -year battle to halt the project, and in the wake of a prefecture-wide referendum, held less than a month earlier, in which $72 \%$ of voters opposed the plan.

On its periphery, Japanese nationalist groups, comprising perhaps no more than 100 individuals, circled noisily in vehicles customised to take on a paramilitary appearance. The pseudo-military convoys, equipped with deafening PA systems, blared out martial music, interspersed with the sounds of emergency sirens, generated to evoke the scenario of a Chinese or North Korean missile attack, to the accompaniment of angry denunciations directed at those who had gathered for the protest.

While advances in audio technology allowed these convoys to create an unprecedented cacophony, the vehicles, bedecked with Japanese Imperial Navy ensigns, as well as the national Hinomaru and Okinawan prefectural flags were otherwise a familiar feature of such relatively small, always flag emblazoned right-wing counter protests.

Photographs of the demonstration itself also reveal a familiar scene of seas of protesters holding placards calling for construction of the base to be halted, entirely, as far as I could see, devoid of any symbols of Okinawan or Ryukyuan identity. ${ }^{1}$

\footnotetext{
${ }^{1}$ Rare exceptions spotted by this author include the appearance of a barely visible independence flag unfurled in a squall during a 23, March 2008 protest following reports of the rape of a 13-year-old Okinawan junior high school girl by a US Marine on 10 February the same year. The flag attracted little or no attention, and was probably neither seen nor recognised by those present.
} 
The purpose of this paper is to seek ways of explaining the relative absence of such symbols in Okinawan protests, and to suggest some historical, ideological and pragmatic explanations for the associated inability of grassroots separatist movements to gain a foothold in the islands.

\section{The Historical Context}

Benedict Anderson's reflections on the emergence of nations and nationalism as "imagined communities," have remained resilient over the three decades since the publication of his most frequently cited work on the subject (Anderson, 1983). Studies of the habitats of residual, emergent, intractable, irredentist, populist and other more or less benign or malignant forms of national allegiance have, since then, if anything, proliferated. At the same time, such movements have also been held responsible for some of the most egregious post WWII acts of violence and human rights violations, particularly in the contexts of the collapse of the Soviet Union, and resistance to the deleterious effects of the global economic order touted as its unipolar successor.

Like many nationalist terrains, the boundaries and topography of Okinawa are complicated by historical circumstances as well internal affiliations. Okinawa island itself, emerged relatively early as the unified Ryukyu Kingdom in 1429 and a tributary state of the Ming Dynasty. Yet, it was not until decades later that it expanded its realm into the southern islands of Miyako and Yaeyama, in the process spawning folk narratives of resistance which continue to reproduce diverse and multiple identities within the archipelago.

During the following century, the kingdom also expanded to the north, eventually encroaching on spheres of influence and economic interest to feudal domains of Japan's southernmost large island of Kyushu. This northern expansion, which also coincided with proto-Japanese warlord Toyotomi Hideyoshi's consolidation of power in Honshu and Shikoku, and his ruinous invasions of Korea, would subsequently become the pretext, as well as proximate cause for the invasion, subjugation and financial bondage of the kingdom under the suzerainty of Kyushu's Shimazu clan from 1609-1879 (Matsuda, 2001; Smits, 1999).

If opportunities for imagining a Ryukyuan nation during the eighteenth century period of European state formation identified by Anderson had already been limited by these events, they were further undermined following the formation of the modern Japanese state in 1868. This was rapidly followed, first by the proclamation of Ryukyu as a Japanese domain in 1872, and then its abolition altogether and annexation into the Japanese polity as Okinawa prefecture in 1879.

The Okinawan annexation transformed the political space from emaciated kingdom into the Japanese nation's least civilised frontier, eventually spawning a romantic mythology of the islands as a repository of Japan's 'old ways,' to be transformed in the process of (re)creating Japan as the beacon of Asian industrialism.

This in turn orientated the islands towards Japan's imperial expansion into Taiwan after 1896, and later to the colonial march into Asia, and final suicidal defence of the "home islands" in 1945 (Earhart, 2005).

This culminated in the carnage of the Battle of Okinawa, the US led invasion and occupation of the islands in the closing months of WWII, which resulted in the deaths of close to a quarter of a million victims, including over 100,000 civilians, or $25 \%$ of the island's pre-war population.

Following five years of direct US military rule, in 1950, the islands were placed under formal American occupation under the jurisdiction of the United States Civil Administration of the Ryukyus (USCAR), a dispensation that was formalised under Article 3 of the Treaty of San Francisco, the 1951 agreement formally ending the American occupation of Japan.

This specified that Japan would give its consent to the ongoing US occupation of the islands pending the establishment of an inconceivable US trusteeship, under the auspices of the United Nations, which was to be established at an indefinite point in the future (Toriyama, 2003). In the same agreement, the United States recognised Japanese 'residual sovereignty' over the islands, apparently leaving open 
the possibility of an end to US military occupation, though, in reality, with the stated purpose of foreclosing debate over Ryukyuan self-determination. ${ }^{2}$

The first decade of USCAR administration witnessed a massive expansion of US military bases, initially coinciding with the development of the island as a cold war 'rampart' during the Korean War and subsequently as the result of a June 1957 agreement to relocate Japanese based American ground forces in their entirety to the island. ${ }^{3}$

Attempts to prevent land seizures during the 1950s are memorialised as the "island-wide struggle,' a collective form of resistance still invoked in ongoing efforts to resist US base construction.

Significantly, however, for the course of future events, after initially evicting resistant Okinawan farmers at bayonet-point and bulldozing their improvised post-war dwellings, USCAR, seeking to pre-empt the possibility of violent civil unrest, placated the population with increased rental payments to private landowners and construction projects designed to promote the development of base hospitality districts. ${ }^{4}$

Meanwhile, with significant, if marginal dissent, anti-base protests coalesced not around the prospect of seeking a sovereignty 'vested in the inhabitants' (see note 1), but rather on the reversion of sovereignty to Japan, and the promise of liberation from military occupation under the umbrella of Article 9 of Japan's peace constitution. ${ }^{5}$

The eventual reversion of Okinawa to Japanese jurisdiction in 1972, left many issues of sovereignty unresolved, among them, the reality that the American military presence remains substantially unchanged. Currently, US facilities continue to occupy almost $20 \%$ of Okinawa Island. In other words, approximately three quarters of all US military bases remain crammed on the island, which constitutes only $0.1 \%$ of the Japanese national landmass, amidst a population of $1.4 \mathrm{~m}$.

\section{"Arresting Emblems"}

Anderson (1983) begins his famous study with what he describes with typical self-effacement as some "simpleminded observations" into sites of national remembrance such as cenotaphs and tombs of unknown soldiers. Speculating on the potential sacrilege of placing human bones in the former, or

${ }^{2}$ John Foster Dulles, at the time Dean Acheson's assistant secretary of state, revealed this sleight of hand, admitting that, "If Japan renounces sovereignty in favor of no one, this would create a chaotic international situation, ... It might then be claimed that sovereignty was vested in the inhabitants, who could hereafter assert, perhaps with United Nations backing, a right to oust the United States." (Cited in Miyazato, 2000: 59).

${ }^{3}$ This resulted in a doubling of the US military presence, and an increase in base density to over a hundred times that in mainland Japan (McCormack \& Norimatsu, 2012).

${ }^{4}$ Toriyama (2003, p.410), cites the following two comments of villagers from communities surrounding new bases in rural northern Okinawa. Quoted in the Ryukyu Shimpo newspaper in the context of their decisions to "accept the situation with resignation" one is recorded to have said, "Our children will be able to continue their education further. Electricity and roads will be set up. Nothing could be better." Another, perhaps in an oblique reference to pre-WWII droughts and famines, is reported to have remarked, "Electrical lighting and running water will be installed. In the future, our children will not have [to] toil as farmers like we had to. This is the way we want things to go."

${ }^{5}$ Douglas Lummis, (personal conversation), has shared anecdotes of how the transfer of ground troops from Japan to Okinawa in the late 1950s was viewed as a triumph for the peace constitution by Japanese activists on the grounds that US troops had been removed from Japanese to US soil. Prominent critics of reversion as a solution to the US military occupation included Arakawa Moriteru, a prominent poet, intellectual and public figure who opposed reversion as being rooted in a Japan-oriented nationalism (Rabson, 2003). 
identifying human remains in the latter, Anderson suggests that though such 'arresting emblems,' may be devoid of identifiable individuals, they are nevertheless, "saturated with ghostly national imaginings." (p.9 - original emphasis).

Okinawa's Cornerstone of Peace, inaugurated on 23 June 1995, to mark the $50^{\text {th }}$ anniversary of the end of the Battle of Okinawa, seems instead to emblemise the antithesis of such imaginings. Built on the site of some of the final horrors of the battle, including civilian mass suicides, the monument consists of over one hundred monument walls arranged in concentric, on which are inscribed the names of all victims of the battle, regardless of nationality, or status as civilians or combatants.

To mark the anniversary, each year, families and descendants of the war dead congregate around the monument, often in scorching summer heat to lay flowers, and often to weep for lost relatives, as well as sometimes visibly unenthusiastically attending a ceremony addressed by the Japanese Prime Minister and the commander of US military forces in Okinawa.

As absent as flags and other parephernalia of national identity at demonstrations, are war heroes or references to the "The Glorious Dead."

\section{Colonial Ideology and the Mythic Language of Imagining Ryukyu}

Surveying the moribund state of Ryukyuan languages at the turn on the millennium, Heinrich (2004) traced the development of a linguistic ideology, often internalised by Okinawans themselves, through which the islands' languages were viewed as impediments to modernisation and development. As well as through the use of the notorious Hogen Fuda, a necklace worn as a punishment in schools by children speaking Okinawan languages, linguistic assimilation was also facilitated through such means as workplace signs warning employees to speak Japanese 'always and everywhere.' This policy, often encouraged by Okinawan language speakers themselves, was also brutally enforced during WWII, as Okinawans caught or suspected of speaking their own languages were subject to summary execution as spies.

Over the last decade and a half, in spite of attempts at highlighting the issue of language endangerment, and ongoing attempts at language revitalisation throughout the archipelago, all six Ryukyuan languages recognised by UNESCO remain endangered or severely endangered.

Yet, even as Okinawa is increasingly imagined by its inhabitants in standard Japanese, residual aphorisms all subtly militate against the formation or articulation of a resurgent separatism.

Three of these, nuchi du takara (life is the only treasure), ichariba chodei (to meet is to become brothers), and nirai kanai (heaven across the sea) are of particular pertinence.

The first, said to have been first uttered by the Ryukyu King as a plea to end armed resistance to the invasion of 1609, and reaffirmed by the tragedies of 1945, renders unimaginable the prospect of Okinawans conceiving the possibility of sacrificing their lives for a nationalist cause.

The second, with roots in Okinawa's maritime history, eschews ethnic assertions of identity, while the third asserts that what lies beyond is a paradise, rather than a threat.

\section{Conclusion}

State formation during the early Ryukyuan period (1429-1609) occurred across a vast geographical space, which involved smaller islands, such as Miyako, and those in the Yaeyama chain to the south, coming under the subjugation of more dominant forces of the Ryukyu Kingdom. Historical memory, as well as cultural differences over these spaces remain impediments to the formation of a unitary narrative of national identity. In addition, subsequent invasions, and particularly the intergenerational trauma of the Battle of Okinawa have created a barren environment imagining war heroes or successful national liberation struggles. 
Illusory promises of liberation from military occupation through reaffiliation with Japanese national identity through reversion may have also contributed to suspicion of all nation building projects.

Given the continuing enormous disparities in power between governments enforcing the ongoing dual subordination of Okinawa to Tokyo and Washington's strategic military interests and Okinawan residents resisting them, as well the bloody recent histories of insurgent nationalisms, Okinawa, for the foreseeable future, may be forgiven for seeking more unified and outward-looking ways of finding "a sovereignty vested in its inhabitants."

\section{References}

Anderson, B., (1983). Imagined Communities. London, U.K.: Verso.

Earhart, S. (2005). Kamekazefication and Japan's Wartime Ideology. Critical Asian Studies. 37(4):569596

Matsuda, M. (2001). The Government of the Ryukyu Kingdom, 1609-1872. Okinawa: Yui Publishing.

McCormack, G. \& Norimatsu, S. (2012). Resistant islands: Okinawa confronts Japan and the United States. Plymouth, UK: Rowman and Littlefield Publishers.

Miyazato, S. (2000). Nichi Bei Kankei to Okinawa. [US-Japan Relations and Okinawa]. Tokyo: Iwanami Shoten.

Smits, G. (1999). Visions of Ryukyu: Identity and Ideology in Early Modern Thought and Politics. ichi Bei Kankei to Okinawa. [US-Japan Relations and Okinawa]. Hawai'i: University of Hawai'I Press.

Toriyama, A. (2003). Okinawa's 'postwar': some observations on the formation of American military bases in the aftermath of terrestrial warfare. Inter-Asia Cultural Studies. 4(3):400-418 